\title{
Improvement of Biological Assay to Determine Available Phosphorus with Growing Chicks
}

\author{
Minoru Yoshida and Hiroshi HosHII \\ National Institue of Animal Industry, Chiba-shi 280
}

In a series of multiple generation feeding experiments with yeast grown on $\mathrm{n}$ paraffin ${ }^{1)}$, it was observed that feed intake and growth rate of the chicks fed $15 \%$ of the yeast during growing stage, i. e., from 0 to 20 weeks of age, were $4 \%$ lower in average than those fed the control diet. Though the yeast is characteristic in high phosphorus and low calcium levels, no adjustment on dietary phosphorus level was done in the yeast diet mentioned above, resulting in slightly higher phosphorus level than the level recommended in Feeding Standard ${ }^{2}$ and in unbalance of calcium and phosphorus levels. It was confirmed later ${ }^{3)}$ that one of the main reasons of lowered appetite and of retarded growth observed on the yeast diet was high and unbalanced phosphorus level in the diet. Feed intake and growth rate of chicks fed an yeast diet, of which phosphorus and calcium levels as well as protein and energy levels were carefully adjusted to be identical to those of the control diet by ommiting dibasic calcium phosphate, were almost exactly identical to those of chicks fed the control diet ${ }^{3)}$. The findings indicate clearly that phosphorus in the yeast must be as available by chicks as phosphorus in dibasic calcium phosphate is. To confirm high availability of phosphorus in the yeast by chicks, it is necessary to establish a biological procedure for estimating availability of phosphorus by chicks.

Most simple way to evaluate biological avilability of phosphorus is to compare growth rate and bone ash content of chicks fed test material to those fed the standard phosphorus source. BARUAH el $a l .^{4)}$ and HijIKuRo et al. ${ }^{5)}$ showed relatively the response of the chicks on the test material by an index taking the response of the chicks on the standard as 100 .

Gillis et $a l .{ }^{6}$ ) first tried to determine quantitatively the availability of phosphorus, based on the linear relationship between dietary level of phosphorus and bone ash content. In the procedure, phosphorus equivalent of the test material is read on the dose-response line against the response of the chicks on the test material. DAmRon and $\mathrm{HARMS}^{7}$ applied this procedure and found large variation of availability of phosphorus in the test material, mainly due to errors in obtaining standard dose-response line and in reading availability on the standard line, although they did not discuss about the error in the estimation. Ammerman et al. ${ }^{8)}$ estimated the regression coefficient between supplemental phosphorus level and bone ash content, and the slopes were compared. Summers et al.9/ took logarithm of supplemental phosphorus and found that log doseresponse curve linear. Accordingly, availability of phosphorus in test materials was estimated by parallel line assay. NeLson and PEELER ${ }^{(0)}$ also found that log dose-response 
curve linear within wider range than dose-response curve is. The parallel line assay based on log dose-response lines on the standard and test materials was reviewed by Nelson and Walker ${ }^{11}$, and used by Dilworth and Day ${ }^{12)}$, Spandorf and Leong ${ }^{13)}$, MotzoK ${ }^{14)}$ and Nelson et $a l .{ }^{15)}$. WALdRoup et $a l .{ }^{16)}$ compared the assay procedures based on log dose and on dose itself and found that similar availability was obtained by the two assay procedure.

HURwiTz ${ }^{17)}$ proposed diflerent way to evaluate biological value based on the net phosphorus utilization, $i$. e., phosphorus retention, per unit of phosphorus taken.

In most of the assays, experimental diets were fed for 3 or 4 weeks ${ }^{4,6,7,9-16,18 \sim 34)}$. AMMERMAN et $a l .{ }^{8}$ ) proposed a rapid method, in which test period is 6 days after 4 days of depletion period, but later, Ammerman et $a l .{ }^{35)}$ reported that the rapid method was inferior to the usual assay procedure of 4 weeks of period.

In supplementing graded levels of standard phosphorus, dietary calcium level was kept constant at $1 \%$, or dietary calcium and phosphorus levels were so adjusted to keep the ratio constant at $2: 1$ in majority of the papers cited in this paper. WALdRoup et $a l{ }^{16)}$ concluded that sliding optimum calcium level for various phosphorus levels is preferable to the other two processes, i. e., keeping calcium level constant at $1 \%$ or keeping calcium and phosphorus ratio constant at $2: 1$, although tibia ash content determined after feeding the diets prepared by one of above 3 processes seemed to be close each other. As for the ratio of dietary calcium and phosphorus levels, it has been repored that the change in the ratio has little eflect on the assay result when the ratio is within $2: 1$ to $1: 1^{14},{ }^{29)}$.

Tibia ash content has been used as criteria for biological availability of dietary phosphorus in most of the assay technique. In one report ${ }^{27)}$, toe ash content, which is much simpler in determination than tibia ash content is and which is used as criteria in vitamin $\mathrm{D}$ assay with chicks ${ }^{36)}$, was used as criteria for phosphorus assay. Ash content of lower beak was reported to be less sensitive to the change in dietary level of available phosphorus than ash content in tibia is ${ }^{35}$.

In this paper, are presented results of studies on the suitable term of experiment, on the effectiveness of toe ash content as criteria and on effect of change in dietary calcium levels. A simplified and rapid biological assay procedure with high accuracy is recommended, which is a slope ratio assay based on linear dose-response relationship.

\section{Experimental}

Four kinds of experiments were conducted. In the first kind of experiment, 79 male White Leghorn chicks and 86 male and 85 female meat-type cross-bred chicks (White Cornish $\mathrm{x}$ White Plymouth Rock) of one-day-old were fed low phosphorus standard diet for 14 days. Twenty chicks each were planned to sacrifice at 8, 10, 12 and 14 days after the start of feeding and to determine ash content of the tibia and toe.

In the second kind of experiment, 340 White Leghorn male chicks of 7-day-old, which were raised on the restricted feeding program $^{37)}$, were divided into two groups 
of equal number and fed the standard diets containing either 0 or $0.3 \%$ of added phosphorus. Twenty chicks each were randomly selected and sacrificed at $6,8,10,12,14$, 21, 28 and 35 days after the start of the experiment. Ash content of the tibia and toe of 5 chicks as a group were determined. Rest of the chicks were discarded at 35 days. Another 20 chicks of the same group were sacrificed at the beginning of the experiment to determine ash contents of the tibia and toe.

In the third kind of experiment, 4 experiments, Expts. 505, 506, 507 and 511 were conducted, in which availability of phosphorus of feed grade dibasic calcium phosphate, fish meal and yellow corn were determined biologically, using the tibia and toe ash contents as criteria. In Expts. 506, 507 and 511, fifteen White Leghorn male chicks each, which were raised on the restricted feeding program $^{37)}$ for one week, were fed the standard and test diets of various phosphorus levels for 10 doys. In Expt. 505, 10 chicks each of meat-type cross-bred chicks of both sexes were treated as White Leghern chicks mentioned above, except the chicks were sacrificed at 8 days because the ricket was observed among the chicks fed the standard diet containing no additional phosphorus. In each experiment, ash content of the tibia and toe of 5 chicks as a group were derermined.

In the fourth experiment, effect of dietary calcium level on the response of the chicks to phosphorus level was studied. Duplicated lots of 5 chicks each of 6 -day-old White Leghorn male, pre-fed on the restricted feeding program $^{37)}$, were fed one of 9 diets, containing 3 levels of calcium, i. e., $0.8,1.0$ and $1.2 \%$, and 3 levels of added phosphorus, $i$. e., $0,0.15$ and $0.3 \%$, in combination for 8 days. The chicks were sacrificed to determine ash content of the tibia and toe.

The chicks in these experiments were reared in an electrically-heated wire-floor battery breeder. Feed and water were given in free access during the experimental period.

Composition of standard and test diets are presented in Table 1. The standard diets contained $3.00 \mathrm{kcal}$ of metabolizable energy/g diet, $20 \%$ of crude protein and $1.0 \%$ of calcium and various levels of added phosphorus from calcium phosphate. As mentioned in Footnote 1 in Table 1, the standard diets were designated by added phoshorus. Only other phosphorus source in the standard diets was soybean meal, which supplied $0.3 \%$ of phosphorus.

To mix various phosphorus sources, dietary cornstarch, cellulose and calcium carbonate were adjusted to keep levels of metabolizable energy and calcium constant. Feed grade dibasic calcium phosphate was added to supply $0.3 \%$ of phosphrus. Fish meal was added to supply $0.184 \%$ of phosphorus. To mix samples of low phosphorus centnet such as cereals, $49.52 \%$ of cereal was mixed with constant part II, of which soybean oil and vitamin B mixture were reduced. Standard and test diets containing various levels of phosphorus were prepared by mixing P-0 standard diet and the diet containing standard or test sources shown in Table 1. For example, $1: 1$ mixture of $\mathrm{P}-0$ and P-0.3 diets gives $\mathrm{P}-0.15$ standard diet.

In Table 2, is presented chemical composition of stanndard and test materials, based on which the composition of the diets presented in Table 1 was decided. Metabolizable 
Table 1. Composition of diet

\begin{tabular}{|c|c|c|c|c|c|}
\hline \multirow{2}{*}{ Ingredient } & \multicolumn{2}{|c|}{ Standard ${ }^{11}$} & \multirow{2}{*}{$\begin{array}{l}\text { Calcium } \\
\text { phosphate } \\
\text { dibasic }^{2}\end{array}$} & \multirow{2}{*}{ Fish meal } & \multirow{2}{*}{ Yellow corn } \\
\hline & $\mathrm{P}-0$ & $\mathrm{P}-0.3$ & & & \\
\hline Constant part $\mathrm{I}^{3}$ ) & $53.4^{\%}$ & $53.4^{\%}$ & $53.4^{\%}$ & $53.4^{\%}$ & $-^{\%}$ \\
\hline Constant part $\mathrm{II}^{4)}$ & - & - & - & - & 48.90 \\
\hline Cornstarch & 37.6 & 37.6 & 37.6 & 32.22 & - \\
\hline Cellulose & 7.32 & 7.22 & 6.62 & 6.67 & - \\
\hline Calcium carbonate & 1.68 & 0.07 & 0.69 & 0.71 & 1.58 \\
\hline Phosphorus source & - & $1.71^{5)}$ & 1.69 & 7.0 & 49.52 \\
\hline
\end{tabular}

1) Designated by added phosphorus from calcium phosphate. For example, P-0 and P-0.3 contains 0 and $0.3 \%$ of added phosphorus, respectively.

2) Calcium phosphate, dibasic, feed grade.

3) Composed of $44.6 \%$ of soybean meal, $0.2 \%$ of DL-methionine, $6 \%$ of soybean oil, $0.5 \%$ of sodium chloride, $0.1 \%$ of trace mineral mixture ${ }^{6)}, 1.5 \%$ of vitamin $\mathrm{B}$ mixture ${ }^{7)}$ and $0.5 \%$ of vitamin $\mathrm{A}$ and $\mathrm{D}$ supplement ${ }^{8)}$.

4) Composed of $44.6 \%$ of soybean meal, $0.2 \%$ of DL-methionine, $2 \%$ of soybean oil, $0.5 \%$ of sodium chloride, $0.1 \%$ of trace mineral mixture ${ }^{6)}, 1.0 \%$ of vitamin $\mathrm{B}$ mixture ${ }^{7)}$ and $0.5 \%$ of vitamin A and D supplement ${ }^{8)}$.

5) Calcium phosphate, tribasic, reagent grade.

6) Composed of $67.28 \%$ of $\mathrm{MnSO}_{4} \cdot 4 \mathrm{H}_{2} \mathrm{O}, 29.91 \%$ of $\mathrm{FeSO}_{4} \cdot 7 \mathrm{H}_{2} \mathrm{O}, 2.43 \%$ of $\mathrm{CuSO}_{4} \cdot 5 \mathrm{H}_{2} \mathrm{O}, 0.29 \%$ of $\mathrm{CoSO}_{4} \cdot 7 \mathrm{H}_{2} \mathrm{O}$ and $0.09 \%$ of $\mathrm{ZnSO}_{4} \cdot 7 \mathrm{H}_{2} \mathrm{O}$.

7) One $\mathrm{g}$ of vitamin $\mathrm{B}$ mixture contained $1.2 \mathrm{mg}$ of thiamine $\mathrm{HCl}, 1.2 \mathrm{mg}$ of riboflavin, $10 \mathrm{mg}$ of niacin, $6 \mathrm{mg}$ of pyridoxine $\cdot \mathrm{HCl}, 4 \mathrm{mg}$ of calcium pantothenate, $170 \mathrm{mg}$ of choline chloride, $100 \mathrm{mg}$ of inositol, $0.5 \mathrm{mg}$ of folic acid, $2 \mathrm{mg}$ of dl- $\alpha$-tocopheryl acetate, $10 \mathrm{mg}$ of para-aminobenzoic acid, $0.05 \mathrm{mg}$ of biotin, $0.06 \mathrm{mg}$ of menaquinone and $5 \mu \mathrm{g}$ of vitamin $\mathrm{B}_{12}$.

8) One $\mathrm{g}$ of vitamin $\mathrm{A}$ and $\mathrm{D}$ supplement contained 10,000 I.U. of vitamin A palmitate and 2,000 I.C.U. of vitamin $\mathrm{D}_{3}$.

Table 2. Chemical composition of standard materials and samples

\begin{tabular}{lcccc}
\hline \multicolumn{1}{c}{ Sample } & Moisture & Crude protein & Calcium & Phosphorus \\
\hline Calcium phosphate, tribasic & 3.38 & $-{ }^{1}$ & $36.7^{\%}$ & 17.5 \\
Calcium phosphate, dibasic & - & - & 22.8 & 17.7 \\
Calcium carbonte & - & - & 39.1 & - \\
Fish meal & 9.63 & 58.9 & 5.42 & 2.63 \\
Yellow corn & 14.36 & 44.9 & 0.01 & 0.26 \\
Soybean meal & 11.51 & & 0.32 & 0.67 \\
\hline
\end{tabular}

1) Not determined.

energy of cornstarch, soybean oil and cellulose were estimated as $3.52,9.21$ and $0 \mathrm{kcal} / \mathrm{g}$. Nine diets used in the fourth experiment were prepared by adjusting calcium phosphate, calcium carbonate, cornstarch and cellulose.

Moisture and crude protein in the standard and test materials were determined by usual precedure for feed analysis ${ }^{38)}$. Their calcium and phosphorus were determined by atomic absorptien analysis and colormetry with vanadomolybdenum reagent, respectively. after extracting the sample itself or the ash of the sample with diluted hydrochloric acid $^{38)}$. Ash content of the tibia and toe was determined as described in Official Meth- 
ods of Analysis of the Association of Official Analytical Chemist ${ }^{36}$.

Slope ratio assay of ash content of the tibia and toe was done as described in the previous paper ${ }^{39}$.

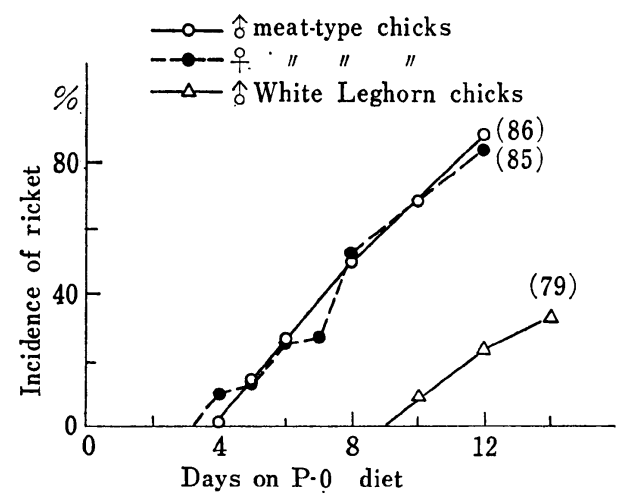

Fig. 1. Cumulative change in incidence of ricket.

(Figures in parentheses are total number of chicks tested)

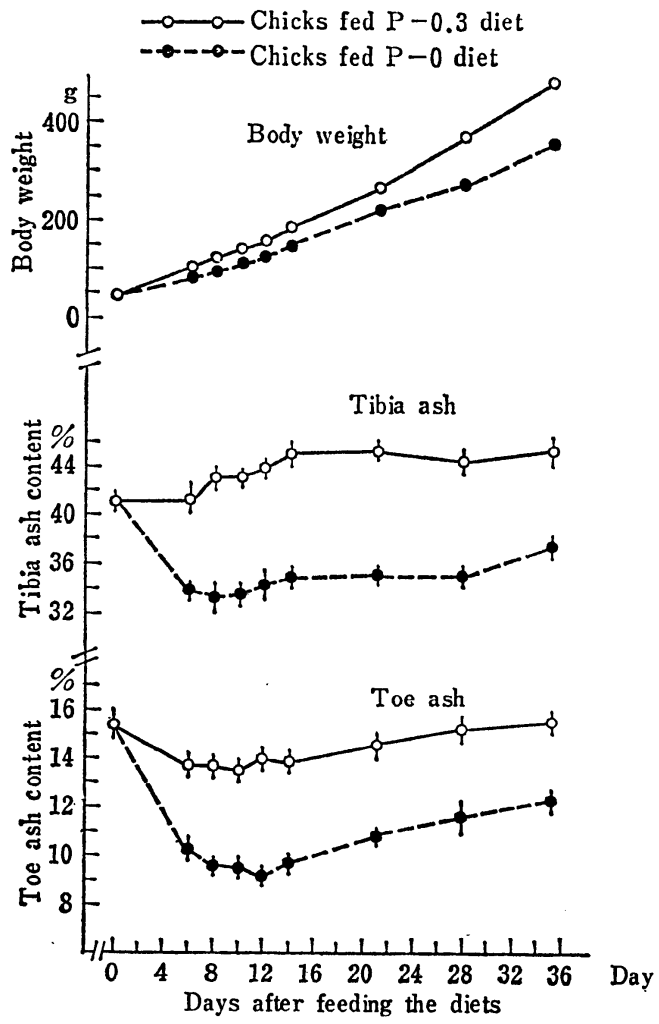

Fig. 2. Change in body weight and ash content of tibia and toe of 7-day-old chicks. (Vertical line indicates standard deviation)

\section{Results}

One-day-old chicks when fed the P-0 diet showed symptoms of ricket. As showh in Fig. 1, clear breed difference in the susceptibility to the ricket was observed, while sex difference was not. Meat-type cross-bred chicks were suffered from ricket at as early as the fourth day on the diet, and the number of chicks suffering ricket increased rapidly to reach almost $90 \%$ at the 12 th day. Incidence of ricket of eggtype chicks was only $33 \%$ at the 14 th day. Difference in incidence of ricket between two breeds of chicks was significnat at $1 \%$ level by $\chi^{2}$-test at the 12 th day.

In Fig. 2, change in body weight and ash content in the tibia and toe of 7-dayold chicks fed either $\mathrm{P}-0$ or $\mathrm{P}-0.3$ diet are presented. As expected previously, growth of the chicks fed P-0.3 diet was faster than that fed $\mathrm{P}-0$ diet. Although not presented in Fig. 2, feed intake of the chicks increased smoothly, and that of the chicks fed P-0.3 diet was more than that fed P-0 diet. The difference in body weight and feed intake between the chicks fed two diets was not so large until after 14 days in the experiment. Ash content of the tibia of the chicks fed $\mathrm{P}-0$ diet and of toe of the chicks decreased after feeding the diets and reached the lowest at $8 \sim 12$ days, then increased gradually. Ash content of the tibia of the chicks fed P-0. 3 diet increased gradually, but was almost the same durings $8 \sim 12$ days after feeding the diet. The trends of the change in ash content of the chicks fed either P-0 or $\mathrm{P}-0.3$ diet were almost parallel, resul- 


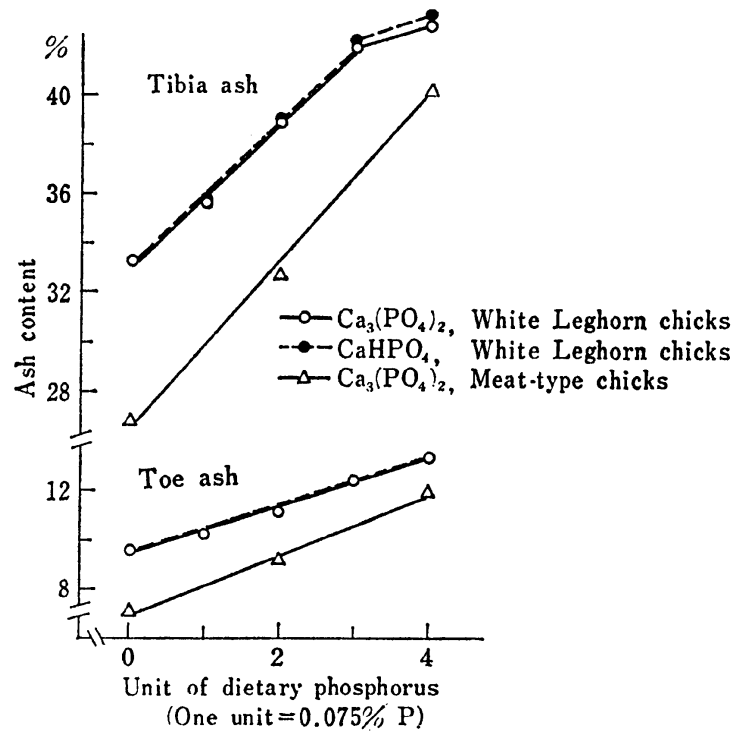

Fig. 3. Change in tibia and toe ash content of chicks fed graded levels of phosphorus (Expts. 505 and 507)

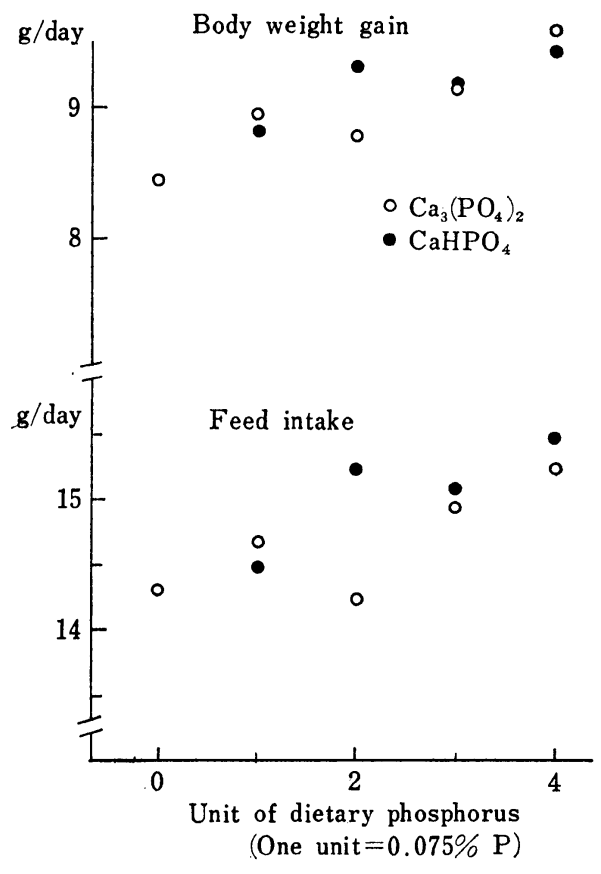

Fig. 4. Change in body weight and feed intake of chicks fed graded levels of phosphorus.

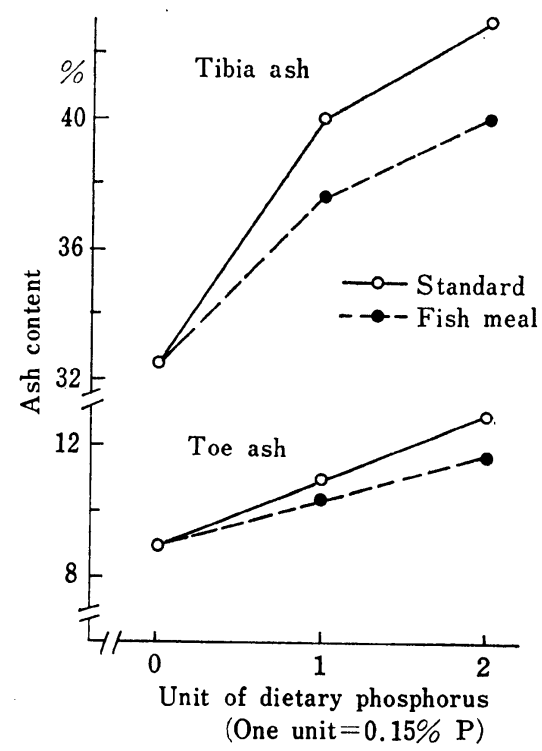

Fig. 5. Charge in tibia and toe ash content of chicks fed graded levels of phosphorus (Expt. 506)

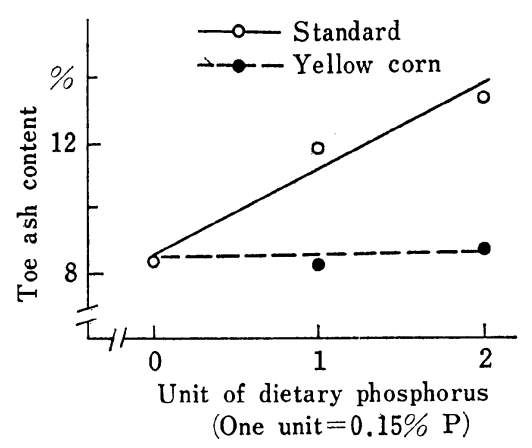

Fig. 6. Changes in toe ash content of chicks fed graded levels of phosphorus (Expt. 511) 
ting in parallel lines as shown in Fig. 2.

Responses of the chicks fed graded levels of phosphorus in Expts. 505, 506, 507 and 511 are presented in Figs. 3, 4, 5 and 6. As shown in Figs. 3, 5 and 6, toe ash content of the chicks was in proportion to the dietady levels of added phosphorus from 0 to $0.3 \%$ while tibia ash content was not always in proportion. Especially, tibia ash content at the highest added phosphorus level was lower than than that expected from ash contents at lower levels. The linear relationship was observed in toe ash content of both eggtype and meat-type chicks as shown in Fig. 3. In contrast, change in body weight gain and feed intake of the chicks fed graded levels of phosphorus varied as shown in Fig. 4 , although the trend of increasing linearly with increase of dietary phosphorus levels was observed. The experimental period of 10 days was too short to obtain clear-cut linear relationship between body weight or feed intake and dietary phosphorus levels.

Availability and its $95 \%$ fiducial interval of feed-grade dibasic calcium phosphate were estimated from the toe ash content in Fig. 3 by 9 -point slope ratio assay to be $99 \%$ and $115 \sim 84 \%$, respectively. The corresponding values estimated from the tibia ash content of chicks fed less than or equal to $0.225 \%$ of added phosphorus by 7 -point slope ratio assay were $103 \%$ and $117 \sim 90 \%$, respectively.

Availability and its $95 \%$ fiducial interval of phosphorus in fish meal were estimated from the toe ash content of the chicks shown in Fig. 5 by 5 -point slope ratio assay to be $109 \%$ and $127 \sim 90 \%$, respectively. In this assay, one unit of added phosphorus from fish meal was $0.092 \%$, while that from standard calcium phosphate was $0.15 \%$. The ratio, $0.092 / 0.15=0.61$, was chosen to make the fiducial interval almost the narrowest ${ }^{39}$ ).

Availability and its $95 \%$ fiducial interval of phosphorus in yellow corn were estimated from the toe ash content shown in Fig. 6 by 5 -point slope ratio assay to be $0 \%$ and $33 \sim-31 \%$, respectively.

Body weight gain and ash content in the tibia and toe of the chicks fed the diet

Table 3. Body weight gain, tibia ash and toe ash of chicks fed diets of various levels of calcium and phosphorus

\begin{tabular}{|c|c|c|c|c|}
\hline \multicolumn{2}{|c|}{ Dietary level } & \multirow{2}{*}{$\begin{array}{c}\text { Body } \\
\text { weight } \\
\text { gain }\end{array}$} & \multirow{2}{*}{ Tibia ash } & \multirow{2}{*}{ Toe ash } \\
\hline $\mathrm{Ca}$ & $\mathrm{P}$ & & & \\
\hline $0.8^{\%}$ & $\%$ & $\begin{array}{r}\text { g/day } \\
5.25\end{array}$ & $33.36^{\%}$ & $9.75^{\%}$ \\
\hline$\prime \prime$ & 0.15 & 7.32 & 38.98 & 11.51 \\
\hline "I & 0.3 & 8.00 & 42.24 & 12.54 \\
\hline 1.0 & 0 & 5.27 & 33.79 & 9.90 \\
\hline$\prime \prime$ & 0.15 & 6.68 & 38.40 & 11.16 \\
\hline$\prime \prime$ & 0.3 & 8.24 & 42.82 & 13.19 \\
\hline 1.2 & 0 & 4.05 & 34.61 & 10.51 \\
\hline "I & 0.15 & 5.95 & 36.19 & 10.63 \\
\hline$\prime \prime$ & 0.3 & 7.63 & 39.74 & 11.63 \\
\hline
\end{tabular}

Table 4. Analysis of variance of effect of dietary calcium and phosphorus levels

\begin{tabular}{|c|c|c|c|c|c|}
\hline \multirow[b]{2}{*}{ Factor } & \multirow{2}{*}{\multicolumn{2}{|c|}{$\begin{array}{l}\text { Degrees } \\
\text { of } \\
\text { freedom }\end{array}$}} & \multicolumn{3}{|c|}{ Mean squares } \\
\hline & & & $\begin{array}{l}\text { Body wt. } \\
\text { gain }\end{array}$ & $\begin{array}{c}\text { Tibia } \\
\text { ash }\end{array}$ & Toe ash \\
\hline \multicolumn{6}{|l|}{ Calcium } \\
\hline Linear & $\mathrm{C}_{\mathrm{L}}$ & 1 & $2.88^{*}$ & $5.45^{*}$ & 0.35 \\
\hline Quadratic & $\mathrm{C}_{\mathrm{Q}}$ & 1 & 0.52 & 2.68 & 0.41 \\
\hline \multicolumn{6}{|c|}{ Phosphorus } \\
\hline Linear & $\mathrm{P}_{\mathrm{L}}$ & 1 & $28.79 * *$ & $177.02^{* *}$ & $17.28 * *$ \\
\hline Quadratic & $\mathrm{P}_{\mathrm{Q}}$ & 1 & 0.24 & 0.03 & 0.09 \\
\hline \multicolumn{6}{|c|}{ Interaction } \\
\hline $\mathrm{C}_{\mathrm{L}} \times \mathrm{P}_{\mathrm{L}}$ & & 1 & 0.34 & $7.01 *$ & 1.40 \\
\hline Residual & & 3 & 0.14 & 1.94 & 0.57 \\
\hline Error & & 9 & 0.33 & 0.84 & 0.30 \\
\hline
\end{tabular}

* and **: Significant at 5 and $1 \%$ levels, respectively 
containing various combination of calcium and phosphorus are presented in Table 3 , and analysis of variance of the data are presented in Table 4. As shown in Table 4, main effect of dietary calcium level and interaction between dietary calcium and phosphorus on the toe ash content were not significant statistically, suggesting that toe ash content varied only in proportion to phosphorus level and that dietary calcium level had little effect on the toe ash content. In contrast, interaction between calcium and phosphorus on the tibia ash content was significant. As shown in Table 3, the trend of increasing tibia ash content in proportion to the increase of dietary phosphorus was observed at 3 dietary calcium levels, and the trend was similar on statistical point of view when dietary calcium level was constant at 0.8 or $1.0 \%$, while the trend, when dietary calcium was at $1.2 \%$, was gentle.

\section{Discussion}

The composition of low phosphorus basal diet was so decided that the level of dietary phosphorus as low as possible with ingredients readily available in this country. The diet produced ricket in newly hatched chicks as shown in Fig. 1, and clear breed difference was observed in the susceptibility to ricket. Although the ricket, when not so severe, seems to have little effect on the ash content of the bone, it is better to exclude the chicks having ricket in the biological assay of available phosphorus. This can be achieved by using 7-day-old White Leghorn chicks reared on the restricted feeding program ${ }^{37)}$. The preliminary restricted feeding program may not be necessary in successful bioassay for available phospeorus, but the program has several merits as mentioned in the previous paper ${ }^{37)}$.

The ash contents of the tibia and toe of meat-type chicks were lower than those of White Leghorn chicks fed the same diet as shown in Fig. 3. The findings are in agreement with those reported by SPANDORF and LEONG ${ }^{13)}$ and GARDINER ${ }^{34}$. However, the responses of both types of chicks to the changs of dietary phosphorus were almost parallel, indicating that both of the chicks can be used in biossay of available phosphorus.

The ash contents of the tibia and toe of 7 -day-old chicks reached almost constant at $8 \sim 12$ days after feeding expermental diets of various phosphorus levels as shown in Fig 2. The content increased gradually, while keeping the difference in ash content between the chicks fed diets of different phosphorus levels almost constant, and resulting in two parallel lines. The findings reveal that 10 days of experimental period is satisfactory for bioassay of available phosphorus to obtain similar conclusion to those obtained in bioassay of 3 or 4 weeks of period. Though not presented in detail in this paper, ash content of the chicks fed the experimental diet from one-day-old was also almost constant at 8 10 days after the start of feeding. As mentioned by AMmERMAN et al. ${ }^{35)}, 6$ days of period may be too short to get stable assessment of available phosphorus.

Toe ash content is useful criteria for biological assay of available phosphosus as of vitamin $\mathrm{D}^{351}$. Besides the simplicity and time- and labour-saving in determination, toe ash is superior to tibia ash, since dose-response curve of toe ash is linear within wider 
range of phosphorus level than that of tibia ash is as shown in Fig. 3 and 5. Correlation coefficient between the tibia and toe of 262 White Leghorn chicks was 0.952 and that of 60 meat-type chicks was 0.929 , both being highly significant statistically.

The relationship between dose, $i$. e., dietary phosphorus level, and ash content in the tibia or toe was linear as shown in Figs. 3, 5 and 6 . The findings are agreeable with those reported by GiLlis et. al.$^{6)}$, but not with those reported by Summers et $a l .{ }^{9)}$ and Nelson and Peeler ${ }^{10)}$, who found linear regression between logarithm of dose and ash content and applied parallel line assay. Correlation coefficients between dose and ash content and between log dose and ash content, calculated by the author using the data presented by Summers et al..$^{9}$ were all significant, except one as shown in Table 5. The findings indicate that doseresponse as well as log dose-response relationships were both assumed to be linear within the range of added phosphorus from 0.028 to $0.111 \%$. It is not necessary to change the dose into logarithm.

Since in parallel line assay described by Summers et $a l^{9}$ availability of phosphorus in the test sample was estimated beforehand, and dietary levels of available phosphorus in the standard and test diets were adjusted to be identical. Under these experimental condition, two regression lines for standard and test diets stood close each other as two lines for tribasic and dibasic calcium phosphates shown in Fig. 3. In such a case, almost identical result will be obtained by either slope ratio assay or parallel line assay. For example, phosphorus availabilities of soft phosphte and phosphoric acid in Expts. 1 and 2 , respectively, in the report of Summers et al. ${ }^{9}$ ) were calculated to be 47.5 and 122 , respectively, by the slope ratio assy on dose-response lines, while those originally reported were 47.5 and 120, respectively, by parallel line assay on log dose-response lines. A sample with phosphorus of low availability can not be assayed by the parallel line, since the lines are not parallel as shown in Fig. 6. Generally speaking, slope ratio assay is superior to parallel line assay.

\section{Recommendation of the standard procedure for estimation of phosphorus availability}

The authors recommend following procedure as the standard procedure for estimation of phosphorus availability.

Preparation of experimental diets: Five diets, a blank containing $0.3 \%$ of phosphorus from soybean meal, 2 diets containing 0.15 and $0.3 \%$ of added phosphorus from standard phosphorus source, and 2 diets containing about 0.09 and $0.18 \%$ of added phosphorus from test material, are prepared, of which composition is as presented in 
Table 1. Either tribaic or dibasic calcium phosphate can be served as standard phosphorus. It is desirable to keep dietary calcium constant at $1 \%$ by adjusting the level of calcium carbonate.

Chicks and rearing: Newly-hatched chicks are preliminarily fed a conventional chick diet under the resticted feeding program of $10 \mathrm{~g}$ per head for initial 3 days and thereafter $3.5 \mathrm{~g}$ per head daily. After 7 days of pre-feeding, chicks were grouped into groups of a certain number of chicks, usually 5, having almost the same body weight. Two to three or more replicated groups are allotted to each of the experimental diet. Feed and water are given in free access. After 10 days, chicks are sacrificed. Middle toe from left (or each) foot is excised by cutting through the joint between second and third digital bone. The toes of 5 chicks as a group are dried for 8 hours or until their weight becomes constant at $100^{\circ} \mathrm{C}$ in air oven, and ashed for 4 hours at $600^{\circ} \mathrm{C}$ in a furnace. Ash content in dried toe is calculated.

Statistical analyses: Error variance among the replicated estimations of 5 chicks each is estimated. When $\mathrm{n}$ test materials are tested in one experiment with $\mathrm{r}$ replications, degrees of freedom of errer variance is $(2 n+3)(r-1)$. Then, phosphorus availability of each test material can be estimated by 5-point slope ratio assay procedure.

Alternative procedures: If necessary, any types of $(2 \mathrm{k}+1)$-point slope ratio assay can be applied. Numbers of chicks in a group and of replication can be increased to increase accuracy of assay. Levels or added phosphate from test material other than 0.09 and $0.18 \%$ can be adopted within the range less than $0.3 \%$. Chicks in replicated group fed the same diet can be reared as one large group with suitably large feeding space.

\section{Summary}

Experimental condition for biological assay of phosphorus availability by chicks was studied. Breed difference was observer in incidence of ricket of one-day-old chicks fed low phoshorus diet containing $0.3 \%$ of phosphorus from soybean meal. Ricket could be prevented by using 7-day-old White Leghorn male chicks reared on the restricted feeding program. Ten days of experimental period was satisfactory to get similar conclusion to those obtained by bioassay of 3 or 4 weeks of period. Toe ash content was superior to tibia ash content. Linear relationship between dietary added phosphorus and toe ash content was observed within the range of added phosphorus from 0 to $0.3 \%$.

A simplified bioassay procedure of ten days of feeding period is recommended, which is a slope ratio assay of linear regression lines between added phosphorus and toe ash content.

Availability and its 95\% fiducial interval of phosphorus in feed grade dibasic calcium phosphate were $99 \%$ and $115 \sim 84 \%$, respectively. Those of phosphorus in fish meal were $109 \%$ and $127 \sim 90 \%$, respectively. Those of phosphorus in yellow corn were $0 \%$ and $33 \sim-31 \%$, respectively. 


\section{Acknowledgement}

The authors wish to express their thanks to Mr. Mikio Ando, National Institute of Animal Institute of Animal Industry, who took charge of atomic absorption analysis of calcium.

\section{Literature}

1) Yoshida, M., M. Tada, H. Bansho, M. Matsushima, K. Koba, M. Iino and I. Umeda: Japan. Poultry Sci., 12, 83, 1975.

2) National Research Council of Agriculture, Forestry and Fishery: Japanese Feeding Standard for Poultry, Central Association of Livestock Industry, Tokyo, 1975.

3) Yoshida, M. and H. Hoshir: Japan. Poultry Sci., 11, 225, 1974.

4) Baruah, J. N., R. E. Davies, B. L. Reid and J. R. Couch: Poultry Sci., 39, 840, 1960.

5) Hijikuro, S., Y. Mohri and H. Morimoto: Japan. Poultry Sci., 4, 19, 1967.

6) Gillis, M. B., L. C. Norris and G. F. Heuser: J. Nutr., 52, 115, 1954.

7) Damron, B. L. and R. H. Harms: Poultry Sci., 49, 1541, 1970.

8) Ammerman, C. B., H. W. Norton and H. M. Scott: ibid., 39, 245. 1960.

9) Summers, J. D., S. J. Slinger, W. F. Pepper, I. Motzok and G. G. Ashton: ibid., 38, $1168,1959$.

10) Nelson, T. S. and H. T. Peeler: 40, 1321, 1961.

11) Nelson, T. S. and A. C. WAlker: ibid., 43, 94, 1964.

12) Dilworth, B. C. and E. J. Day: ibid., 43, 1039, 1964.

13) Spandorf, A. H. and K. C. LeONG: ibid., 44, 1107, 1965.

14) Мотzок, I.: ibid., 47, 967, 1968.

15) Nelson, T. S., T. R. Shieh, R. J. Wodzinski and J. H. Ware: ibid., 47, 1842, 1968.

16) Waldroup, P. W., C. B. Ammerman and R. H. Harms: ibid., 44, 1086, 1965.

17) Hurwitz, S.: J. Nutr., 84, 83, 1967.

18) Sieburth, J. F., J. McGinnis, T. Wahl and B. A. Mclaren: Poultry Sci., 31, 813, 1952.

19) Harms, R. H., P. W. Waldroup and B. I. Damron: ibid., 46, 981, 1967.

20) Damron, B. L. and R. H. Harms: ibid., 47, 1878, 1968.

21) Andrews, T. L., B. L. Damron and R. H. Harms: ibid., 50, 104, 1971.

22) Christmas, R. B., B. L. Damron and R. H. Harms: ibid., 50, 596, 1971

23) Andrews, T. L., B. L. Damron and R. H. Harms: ibid., 50, 1485, 1971.

24) Andrews, T. L., B. L. Damron and R. H. Harms: ibid., 51, 1171, 1972.

25) McGinnis, J., L. C. Norris and G. F. Heuser: ibid., 23, 157, 1944.

26) Gillis, M. B., L. C. Norris and G. F. Heuser: ibid., 28, 283, 1949.

27) Grau, G. R. and P. A. Zweigart: ibid., 32, 500, 1953.

28) Creech, B. G., B. L. Reid and J. R. Сouch: ibid., 35, 654, 1956.

29) Vandepopuliere, J. M., C. B. Ammerman and R. H. Harms: ibid., 40, 951, 1961.

30) Waldroup, P. W., C. B. Ammerman and R. H. Harms: ibid., 43, 426, 1964.

31) Waldroup, P. W., C. B. Ammerman and R. H. Harms: ibid., 44, 880, 1965.

32) MotzoK, I., D. Arthur and S. J. Slinger: ibid., 46, 985, 1967.

33) Summers, J. D., W. F. Pepper, H. S. Bayley and S. J. Slinger: ibid., 47, 1397, 1968.

34) Gardiner, E. E.: ibid., 48, 986, 1969.

35) Ammerman, C. B., C. R. Douglas, G. K. Davis and R. H. Harms: ibid., 40, 548, 1961.

36) "Official Methods of Analysis of the Association of Official Analytical Chemists" 11 th ed., 1970.

37) Yoshida, M.: Japan. Poultry Sci., 10, 104, 1973.

38) Mовimoto, H., supervised: Experimental Method in Animal Nutrition, Yokendo, Tokyo, 1971.

39) Yoshida, M.: Japan. Poultry Sci., 13, 186, 1976. 


\title{
ヒナによるリンの利用率の測定法の改善
}

\author{
吉田 実・星井 博
}

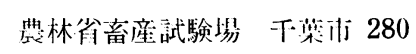

ヒナによるリンの利用率の生物定量法におおける笑験条 件を検討した。初生ヒナに，火豆粗からのリン $0.3 \% を$ 含も低リン飼料を与えると，クル病がみら机その発生率 は鵎種間で差が認められた。クル病は制限給与して育成 した 7 日齢の白レグ種雄ヒナを使䏔することにより防ぐ ことができた。実験期閒は 10 日で十分であって, 3 週も しくは4 週間の生物定量法の場合と同じ結論がえられ る。脛骨灰分にもとずくより，趾灰分にもとづく測定の ほうがすぐれていた。飼料に添加したリンの含量が，0 $\sim 0.3 \%$ 以下の条件でリン添加量と趾灰分との間に直線
归係が涊められたた。

これらの実験つ絬果からリン涯加量と趾灰分含量とり 直線開係にもとづき傾斜比法沉より測定する 10 日閒の 簡単な生物定量法を提唱した。

飼料用リン酸 2 カルシウムのリンの利用率とその $95 \%$ 信頼区間は，99\%と 115〜84\%であった。魚粉のリンに ついては，それぞれ 109\%と127〜90\%であり，黄色卜 ウモロコシのリンについては，そ机でれ０％と33〜-31 \%であった。

（家畕会誌，14，33４4，1977） 